
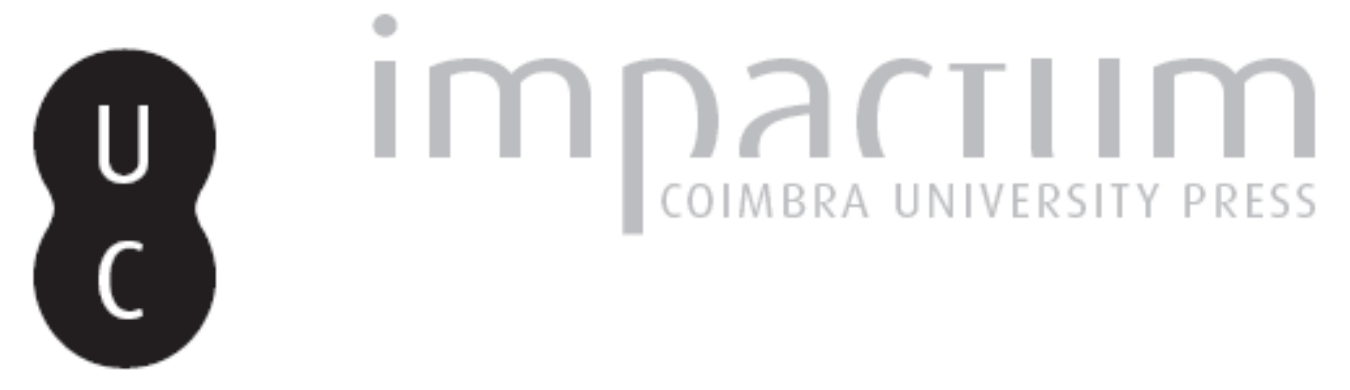

\title{
Invisible cities: utopian spaces or imaginary places?
}

Autor(es): $\quad$ Martins, Ana Isabel Correia

Publicado por: Imprensa da Universidade de Coimbra

URL persistente:

URI:http://hdl.handle.net/10316.2/43393

DOI:

DOI:https://doi.org/10.14195/1984-249X_22_5

Accessed : $\quad$ 26-Apr-2023 14:57:37

A navegação consulta e descarregamento dos títulos inseridos nas Bibliotecas Digitais UC Digitalis, UC Pombalina e UC Impactum, pressupõem a aceitação plena e sem reservas dos Termos e Condições de Uso destas Bibliotecas Digitais, disponíveis em https://digitalis.uc.pt/pt-pt/termos.

Conforme exposto nos referidos Termos e Condições de Uso, o descarregamento de títulos de acesso restrito requer uma licença válida de autorização devendo o utilizador aceder ao(s) documento(s) a partir de um endereço de IP da instituição detentora da supramencionada licença.

Ao utilizador é apenas permitido o descarregamento para uso pessoal, pelo que o emprego do(s) título(s) descarregado(s) para outro fim, designadamente comercial, carece de autorização do respetivo autor ou editor da obra.

Na medida em que todas as obras da UC Digitalis se encontram protegidas pelo Código do Direito de Autor e Direitos Conexos e demais legislação aplicável, toda a cópia, parcial ou total, deste documento, nos casos em que é legalmente admitida, deverá conter ou fazer-se acompanhar por este aviso. 


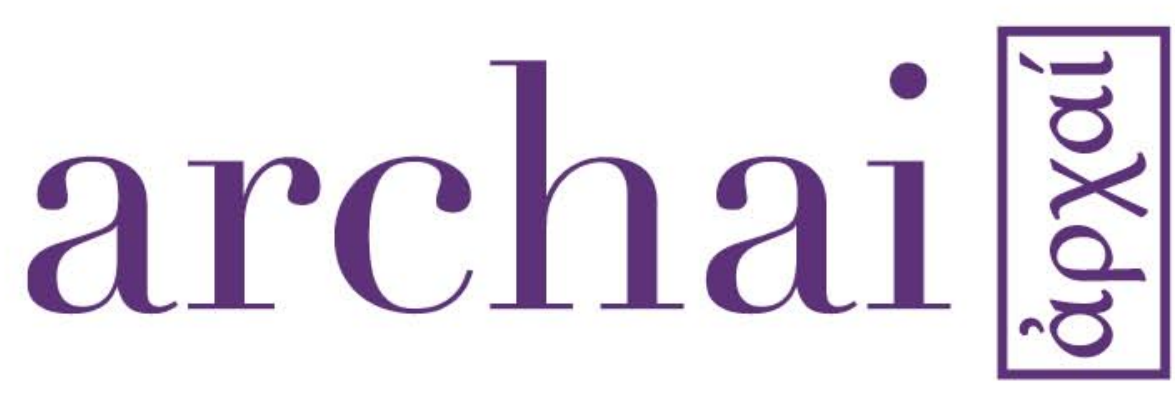

Revista sobre as origens do pensamento ocidental Journal on the Origins of Western Thought

22 | Jan.-Apr. 2018 


\section{INVISIBLE CITIES: UTOPIAN SPACES OR IMAGINARY PLACES?}

MARTINS, A. I. C. (2018). Invisible cities: utopian spaces or imaginary places?. Archai, n. ${ }^{\circ}$ 22, Jan.-Apr., p. 123-152

DOI: https://doi.org/10.14195/1984-249X_22_5

Abstract: Like Raphael Hythloday, Marco Polo narrated his journey to Kublai Khan, the Emperor of the Tartars, presenting a catalogue of places and a cartography of 55 cities. The magic realism of Italo Calvino, the lush and synaesthetic descriptions in Invisible Cities (1972) construct a symbolic imaginarium of utopian paradigms. The taxonomy of all these cities sheds light on their relationship to man: cities and memory, cities and desire, cities and signs, cities and eyes, cities and names, cities and the dead, cities and the sky, continuous cities and trading cities. Some of them have an indivisible existence whilst others contain contradictions, some are more ethereal and others much more tangible, but all of them are real in the imagination and only inhabit an abstract space. Could we define them as "nonplaces" or "good-places"? Their geometries are different and whilst some represent what is necessary but does not exist yet, others represent what is potentially imaginable and credible but not achievable: could this be a coherent definition of utopia? Are there cities that are too believable to be true? This article archai圈

no 22, Jan.-Apr. 2018 


\section{archai圈}

no 22, Jan.-Apr. 2018

Ana Martins, 'Invisible cities: utopian spaces or imaginary places?', p. $123-152$ aims to reconstruct the main lines of Utopia's genealogy, regarding the socio-political desire for the ideal state, from Plato to Italo Calvino, answering these two main questions: are ideal cities utopian spaces or imaginary places? Does utopia therefore fail where reality begins?

Keywords: magic realism, boundaries and limits, utopian city, imagination

\section{UTOPIAN AIMS AND THEIR SCOPE}

\section{o.1. THE MAgIC REALISM OF INVISIBILITY}

The quantity of things that could be read in a little piece of smooth and empty wood overwhelmed Kublai; Polo was already talking about ebony forests, about rafts laden with logs that come down the rivers, of docks, of women at the windows... (CALVINO, 1974, p. 132)

Italo Calvino presents a catalogue of places, a cartography of fifty-five invisible cities, constructing a symbolic imaginarium of utopian paradigms described by Marco Polo to Kublai Khan, the Emperor of the Tartars and all these descriptions are intertwined by eighteen dialogues between both. Six specific groups of critics can be identified, distinguished by their methodology and overall perspective on Calvino's work: the first usually assumes that philosophy is the fundamental aspect of his work; the second emphasises the relationship established with the reader and his horizon of expectations from a rhetorical and aesthetic point of view, exploring the ekphrastic nature of language; the third typically analyses him as a unique literary figure, highlighting 
the features of magic realism from a poetic point of view; the fourth explores a nexus of values mainly concerned with morality and the ethics of social interactions; the fifth reflects on the semantic and pragmatic evolution of the term, with reference to the ambiguity of outopia and eutopia; finally, the sixth group discusses the political potential of the ideal state from a historical point of view, ranging from Plato and Aristotle to More's model of justice and his influence on Montaigne, Francis Bacon, Tomasso Campanella, Guillaume Budé, Thomas Lupset, U1rich Von Hutten, Lorenzo Valla, Boccaccio, Rabelais and Erasmus ${ }^{1}$ during the Renaissance, but also shedding light on the nineteenth and twentieth centuries. In fact, a thoroughgoing analysis of Calvino's utopia would involve an interdisciplinary approach, since utopia itself displays an enormous range of configurations and is an intriguing polysemic subject that contains both ideological and literary aspects.

In Invisible Cities, accordingly Ernst Bloch (1988), the potential of utopia is determined by its anticipatory illumination and illusion, as an image through which we gain a sense of truth in reality. Therefore, if we want to answer the question are invisible cities utopian spaces or imaginary places this must involve several key concepts and their hyponymic hierarchy: desire, myth, truth versus verisimilitude, memory, symbol, scheme, fruitfulness, power and humanism. Undoubtedly, Invisible Cities emerged from Calvino's desire to write about ideal cities and ideal human relations, for this reason, the cities themselves are not simply sad or blissful, utopian or dystopian, disconnected from human desires and their shadows, their social networks and aspirations. The author reveals

\section{archai莀}

no 22, Jan.-Apr. 2018

Ana Martins, 'Invisible cities: utopian spaces or imaginary places?', p. 123-152 


\section{archai圈}

no 22, Jan.-Apr. 2018

Ana Martins, 'Invisible cities: utopian spaces or imaginary places?', p. $123-152$ how the idea of the city is part of the process of desire's construction, how desires are projected onto the cities, how the cities themselves affect the nature of desire and how both cities and desires change through their perpetual confrontation. Concerning this point, could the definition of utopia be endless and changeless, circumscribed within a particular time and space?

In order to answer these questions, the taxonomy of all these invisible cities sheds light on their relationship with man, touching on several issues such as humankind's relationship with the past and the construction of cultural identity, the idea of individual progress and social improvement, determinism and free will, and, above all, man's most profound desire to understand, reconstruct and establish a dialogue with the world he lives in. In order to achieve this purpose, Jenny Webb (2011) explains that the function of myth draws both on the desire for knowledge and the creative impulse, and its symbolic power is therefore a tool for reinterpreting and revalidating the matrixes responsible for every human intellectual activity.

Desire is the engine of utopia, so before exploring the construction of utopia in Calvino's work, the different types of human desire, in the specific sense of curiosity and aspiration, must be recognized: the desire for self-knowledge, reflected in Khan's desire to know his empire, as well as Marco Polo's desire to know himself through his travels; the desire to know others, mainly revealed during the dialogue between the emperor and Marco Polo. There is also the desire to know the world for which the cities serve as a working metaphor, wishing for a model and a paradigm that do not yet exist but at the same time represent what is 
potentially imaginable and credible but not achievable. Utopia expresses man's essence, his inner and main aim of opening up several possibilities of existence. Utopia hovers suspended between possibility and impossibility, which is why Marco Polo says: "I cannot force my operation beyond a certain limit: I would achieve cities too probable to be real" (CALVINO, 1974, p. 69).

\section{o.2. Could we have a memory of A Future desire?}

Perhaps, Kublai thought, the empire is nothing but a zodiac of the mind's phantasmas. "On the day when I know all the emblems" he asked Marco, "shall I be able to possess my empire at last?" and the Venetian answered: "Sire, do not believe it. On that day will be an emblem among emblems (CALVINO, 1974, p. 23)

The framework of the book is structured around the communication between Marco Polo and Kublai Khan as a hermeneutical engine. If the first body of text contains the dialogue between these two main characters the second presents Marco Polo's fantastic descriptions of the cities. This internal articulation deep an effect of incantation and although these cities do not exist, the emperor at times accuses his messenger of lapsing into melancholy instead of reporting on the state of the different regions in his empire. In fact, Marco Polo's memories are, at the same time, topoi of imagination, a projection of his future desires and wishes, and also an expression of his mindscape and his understanding of world. These cities are a result of how he interprets the world and how he projects his subjectivity onto it.

\section{archai或}

no 22, Jan.-Apr. 2018

Ana Martins, 'Invisible cities: utopian spaces or imaginary places?', p. $123-152$ 


\section{archai圈}

no 22, Jan.-Apr. 2018

Ana Martins, 'Invisible cities: utopian spaces or imaginary places?', p. $123-152$
Their ancient, mythical and classical names give the cities a utopian dimension at times often associated with fantastic elements and representing symbols that have no correspondence in reality:

Le XIXe siècle vivait dans une métaphysique du réel et de l'imaginaire et la littérature fantastique n'est rien d'autre que la mauvaise conscience de ce XIX siècle positiviste. Mais aujourd'hui on ne peut plus croire à une réalité immuable, externe, ni à une littérature qui ne serait que la transcription de cette réalité. Les mots ont gagné une autonomie que les choses ont perdue. [...] La Littérature fantastique elle-même, qui subvertit tout au long de ses pages, les catégorisations linguistiques en a reçu un coup fatal; mais de cette mort de ce suicide est née une littérature nouvelle. (TODOROV, 1970, p. 176)

It is pertinent to underline that one structural marker of the utopian text is its verbal inventiveness, the creation by these writers of extravagant place names that are not without symbolic, if at time ambiguous, meaning. This penchant for neologism would appear to emphasise the close link between the utopian text, magical-utterance and imaginative construction of reality. Language is therefore central to the utopian text, both as a linguistic negotiation game of invention or a kind of lexical and semantic challenge which the reader must take up in an attempt to correctly decode the text. It is undeniable the need to create a new idiom which will be the vehicle for the new society's construction, as a set of pure and perfect terms in which to couch the perfection of the new world space.

Lutopie est organisation de l'espace comme texte et discours construit comme espace; mais elle est produite par 
la pratique utopique que s'y révèle et $s^{\prime} y$ cache sous la forme d'un jeu de lignes à déchiffrer; jeux s'espace dans lesquels le temps se résume, s'accomplit et s'abolit, mais jeux de lettres aussi, jeux de signifiants dans le système du texte. (MARIN, 1973, p. 25)

The quality and the scope of Marco Polo's descriptions is measured by their capacity to remain carved into his audience's memory: "Memory's images, once they are fixed in words, are erased,» Marco Polo says: «Perhaps I am afraid of losing Venice all at once, if I speak of it. Or perhaps, speaking of other cities, I have already lost it, little by little" (CALVINO, 1974, p. 87). For this reason, the richness of Calvino's literary proposal is its ekphrastic potential; the mental images conquer their own autonomy, since the image of the city will be explored in its multiple iconic forms and functions as the trigger for the fictional and creative process, as sign, as content and as form. When Marco Polo describes Olivia, he is conscious that falsehood never lies in words but in things and a lie and a falsehood are different concepts. A certain degree of tension and ambiguity should be seen as inherent to the construction of utopia. The relation between art and literature is related to this concept of memory as the capacity to recall impressive images, evoke well-known roots and create chains of associations that lead from one image to the other. For this reason, metonymy, metaphor, allegory and the rhetorical figure metalepsis are essential tools for symbolic construction and utopian thinking, intrinsically related to the creative process and the imagination, and developed extensively since Aristotle (Poetics 1457b1-1458a17).

\section{archai圈}

no 22, Jan.-Apr. 2018

Ana Martins, 'Invisible cities: utopian spaces or imaginary places?', p. $123-152$ 


\section{archai圈}

no 22, Jan.-Apr. 2018

\section{Ana Martins, 'Invisible} cities: utopian spaces or imaginary places?', p. $123-152$
La metaforicidad es un âmbito ligado a las más primordiales realidades humanas: a partir de la metáfora se constityen para nosotros el mundo, lenguaje y pensamiento. El pensar metafórico es el modo esencial humano de hacer (actio), decir (oratio) y conocer (logos); el modo desde el que originariamente se abren al mundo, desde la intimidad de uns imagen, el hecho, la palabra y la idea. (FERNÁNDEZ, 2000, p. 11)

Images are reinvented, regenerated and enriched in a process of reading and interpretation and, whilst the passage from word to image is the reader's responsibility, the transition from image to word lies with the writer, through a permanent challenge "the city exists and it has a simple secret: it knows only departures, not returns" (CALVINO, 1974, p.56). Calvino's images have a mimetic role, representing and reinterpreting reality, whilst also reflecting the imagination of the potential future on an invisible level: "Au niveau de l'imagination, le discours utopique fonctionne non comme une icône, mais comme un schème. Lutopie se spécifie comme figure. Produit dans la distance des contradictoires, il est le simulacre de la synthèse tout en signifiant la contradiction qui l'a produit" (MARIN, 1973, p. 26).

The cities described are a result of dealing with desire, aspiration, existence, personal experience, dissatisfaction, reality and are therefore sometimes considered concrete visual images, and at other times mental and also verbal images. The reader knows that the dialectical dynamic of visible/invisible can be interpreted in two different ways: invisibility may be an intrinsic quality of the cities - without real correspondence - and/or the eye that looks at them may not be sensitive enough to see them. The dual nature of the invisibility of the cities is closely 
related to the traveller's way of looking at the world, since the cities are a product of Marco Polo's imagination, his projections, mindscape and inner world.

However, when we talk about imagination and invisibility we are not necessarily talking about fantastic literature as the equivalent of magic realism, since the world of utopia is not inhabited by gnomes, goblins, dragons and fairies but by human beings:

Lultima componente stilistica rilevata da Calvino è l'agilità, l'efficacia compositiva che deriva dalla «fantasia degli esempi». Lassioma allude a due momenti estetici distinti, il primo incentrato sulla fantasia come funzione creative della immaginazione, sempre alla ricerca di una espressione per manifestarsi, il secondo sulla fantasia come varietà, diversità e originalità. La fantasia diviene indizio di un procedere stilistico e di un gusto letterario moderni, in cui, secondo Calvino, il «pensar bene» è collegato ad una certa rapidità mentale che nell'emittente diviene creazione associativa lucida, scattante, compressa ma leggera, e nel ricevente si risolve nella abilità di incamerare le immagini e moltiplicarne i significati. (WRIGHT, 1998, p. 141).

The magic realist writer is searching for a probable and feasible reality, a variation of status quo, not necessarily a (land)scape; he is committed to the problems and engaged with social movements, and reality is just a palimpsest of rewritten, reinvented scenarios. Instead of fleeing the world, the author is immersed in reality, elevating fascination beyond entertainment.

En ningún caso deben confundirse realismo mágico y literatura fantástica. En esta última, el narrador puede

\section{archai圈}

n 22, Jan.-Apr. 2018

Ana Martins, 'Invisible cities: utopian spaces or imaginary places?', p. 123-152 


\section{archai圈}

no 22, Jan.-Apr. 2018

\section{Ana Martins, 'Invisible} cities: utopian spaces or imaginary places?', p. $123-152$

\section{2}

situar la acción, el tiempo o los personajes en una dimensión contraria a la lógica del mundo racional. Gracias a su libertad imaginativa, lo que resulta imposible en el orden físico se hace posible en el fantástico. El narrador fantástico no conoce límites para clausurar las leyes del orden natural en favor de todo tipo de prodigios, milagros y elementos sobrenaturales. Por el contrario, en el realismo mágico, el prodigio, el milagro, lo extraño y anormal está dentro y sujeto a las leyes del mundo, aunque su sola existencia nos causa sorpresa. En vez de presentar la magia como si fuera real, el narrador nos presenta la realidad como si fuera mágica (DELGADO, 2006, p. 20).

Travel is also self-knowledge itinerary and a discovery so all the cities are the result of how Marco Polo interprets the world and how he projects his subjectivity onto it. When Khan asks him to talk about the arch and not about the stones that support it, he probably means that he wants an overview of the construct; he would rather Marco Polo adopted a holistic approach to telling stories. Marco Polo explains that the arch is inconceivable without the stones or, in other words, the whole cannot be described without referring to the parts: "journeys to relive your past? Is Khan's question at this point, a question which could also be formulated as "Journeys to recover your future? Marco Polo's answer is: "Elsewhere is a negative mirror. The traveller recognizes the little that is his discovering, the much he has not had and will never have" (CALVINO, 1974, p. 29).

\section{The genealogy of Utopia: The socio-} -POLITICAL DESIRE FOR THE IDEAL STATE

At this point Kublai Khan interrupted or imagined interrupting him, or Marco Polo imagined himself interrupted 
with a question such as: "You advance always being you? Or rather "Does your journey take place only in the past? (CALVINO, 1974, p. 28).

The analytical study of utopia has a long tradition dating back to the Greeks and Plato is considered the founder of the genre. However, it should be emphasised that The Republic and Laws are more projects for legislation than for constructing utopias, given that the Peloponnese War had created a great deal of dissent and social vulnerability. Thus, in this context, Plato presents an ideal of cohesion and solidarity, a strong and fair state able to protect the citizens: "un tableau descriptive, d'une société en plein fonctionnement. Dirigisme, eudémonisme collectif, institutionnalisme, idéal communautaire, système déducation publique sont des éléments de base que Platon léguera à bon nombre d'utopistes" (TROUSSON, 1975, p. 34). On the other hand, Timaeus and Critias reveal a matrix of changing desires: in the opening of the first dialogue, Socrates recalls the principles of the ideal republic and also voices his vague dissatisfaction with mere discourse on the framework of the ideal city, as expressed in The Republic. Nineteen centuries later Thomas More, influenced by Plato, finally achieved the Socratic wish in his Utopia, influencing his contemporaries and successors. Ideal cities have been presented as more than simple imaginary portraits reducible to socio-cultural, historical or psychological factors. Extending beyond these - certainly not insignificant - influences, they share a common purpose: to express the pure relationship of man to humanity in the form of a social order which, on its boundaries, loses the character of a political solution and reveals its meta-empirical nature. The question that arises is not

\section{archai蒡}

no 22, Jan.-Apr. 2018

Ana Martins, 'Invisible cities: utopian spaces or imaginary places?', p. $123-152$ 


\section{archai圈}

no 22, Jan.-Apr. 2018

\section{Ana Martins, 'Invisible} cities: utopian spaces or imaginary places?', p. $123-152$ why cities are so often the locus of utopia but why did so many of the characteristic institutions of utopia first come to light in the ancient city.

If we want to analyse utopia through the eyes of the Greeks and in particular through Plato's approaches, the utopian focus is developed in four of his dialogues, being the most influential The Republic. Although Plato has been accused of subordinating the individual to the state, in fact, he subordinates the state to the individual because the main focus is the search for justice in the individual practice. The roots of politics lie in economics and his formula for an ideal commonwealth is to establish the right people in the ruling class, the right education and the right way of life for them. In addition to these material conditions, it is important to emphasise their relationship to citizens, since every society is a healthy body whose vitality is closely linked to the role of each of its members. Plato's ideal community begins at the point when the early Golden Age comes to an end, with absolute rule, totalitarian enforcement, the permanent division of labour and constant readiness, with everything accepted in the name of justice and wisdom. The city that Plato portrays is a self-contained unit which, in order to ensure this self-sufficiency, must have enough land to feed its inhabitants and make it independent of any other community: it is an autarchy, a very similar matrix with More's utopia. The population of this community is divided into three main classes: husbandmen and craftsmen, a large mass of people who attend to the economic and general life of the community; the 'second' class of guardians, with military and executive functions; the philosopher-rulers, to whom everything is subordinate: "Plato reinforces 
his conclusion, that political troubles will persist until philosophers become rulers or rulers take seriously to the study of philosophy, that is until political authority and the pursuit of wisdom coincide" (FERGUSON, 1975, p. 67).

Plato rationalized kingship and if one thinks of Plato's scheme as a contribution to an ideal future, it must be wondered why justice, temperance, courage and wisdom had never before been addressed to such a contradictory ideal outcome. What Plato had actually accomplished was not a means of overcoming the weaknesses that threatened the Greek commonwealth of his day, but the establishment of a seemingly philosophical basis for the historic institutions that had, in fact, arrested human development. He proposed to create a structure that, unlike that actual city in history, would be immune to challenge from within and to destruction from without. Plato's utopia or ideal city represented the final consummation and the corollary of our supposedly dynamic society. In order to fulfil this ideal, Plato makes his republic immune to change: once formed, the pattern of order remains static, as in the insect societies to which it bears a close resemblance. With the aid of ideals, every community may select from a multitude of possibilities those which are consonant with its own nature or that promise to further human development and improvement:

Ce premier modèle utopique ne pouvait manquer de stimuler les imaginations; à l'Atlantide vinrent s'ajouter des fables populaires sur l'âge d'or, Le Champs Elysées ou les

\section{archai圈}

no 22, Jan.-Apr. 2018

Ana Martins, 'Invisible cities: utopian spaces or imaginary places?', p. $123-152$ 


\section{archai圈}

no 22, Jan.-Apr. 2018

Ana Martins, 'Invisible cities: utopian spaces or imaginary places?', p. $123-152$
Iles fortunes. Le désir spontané d'un people épris d'art et de récits, soucieux de donner une forme à ses rêves de bonheur, ce désir rencontra, au siècle suivant, un ensemble de circonstances particulièrement favorables à l'éclosion définitive d'une genre qui cherchait encore sa voie. (TROUSSON, 1975, p. 38)

Aristotle in Book II of the Politics criticizes this Plato's scheme under the conviction that certain "ideal states" demand critical examination, attacking the community of family relationships on the general grounds that Plato 'waters down' affection (Arist. Polit. 2.1262b.16). One of these arguments lies on the ideal of static perfection because this is a dead ideal, not a living one, as later discovered when he was forced to admit life and movement into the world of forms and he had also studied and criticized other ideal commonwealths. Ethics and Politics are, for Aristotle, separate aspects of the same subject and if at the beginning of his Ethics he affirms that every science, every subject, every action and every choice appear to aim at some good so good is legitimately defined as the object to which all things aspire. The concept of utopia pervades every page of the Politics and his utopian perspective extends beyond this, presenting the archetypal form and comparing one kind of city with another, not just in terms of political power but also the ideal and social values for human development. On the one hand, Aristotle considers the polis as an (arte)fact of nature, since man is a political animal who cannot live alone. However, since it is equally true that the polis is a human artefact, its inherited constitution and its physical structure may be criticized and modified by reason and the polis was therefore potentially a work of art. Aristotle's concern 
is to find the form of political community that could be the best and the most able to achieve their ideal of life. Concerning Hellenic thought, the utopian city involves certain key concepts such as isolation, stratification, fixation, regimentation, standardization and militarization.

During the Renaissance, a distinctive pattern of utopian narrative emerged, promoted by Sir Thomas More, reflecting all these political principals and forms of social organization and drawing on the classical model for the ideal state. In Thomas More's hands the expression takes on a new and distinctive form, developing the interest in urbanism and in geographic projection of human being and its relationships as a social construction: "A leurs plans grandioses de villes aux traces rectilignes, ils ajoutent le désir de réglementer la vie des habitants, de faire de la cite une ruche minutieuse où chacun trouve sa place et sa fonction. Déjà le De re aedificatoria de Léon Battista Alberti, rédigé en 1452 témoigne de ce dépassement de l'architecture vers la construction sociale" (GRENDLER, 1965, p. 499).

The complex and contradictory nature of the utopian fictions of the Renaissance is a consequence of the ideological ferment and a multimodal dynamic of the period in which they were written, inextricably linked to the symbiotic relationship between revolutionary ideas and a powerful commitment to tradition - imitatio ac renouatio. Utopia (1516) is neither a manifestation of nostalgia for the past nor a millennial dream for the future, but the influence of Plato, in particular, proved a powerful stimulus to new ways of looking at the world, reinforcing as it did the

\section{archai蒡}

n 22, Jan.-Apr. 2018

Ana Martins, 'Invisible cities: utopian spaces or imaginary places?', p. $123-152$ 


\section{archai圈}

no 22, Jan.-Apr. 2018

\section{Ana Martins, 'Invisible} cities: utopian spaces or imaginary places?', p. 123-152 sense that contemporary society had much to learn from the example of a past civilization were at least as sophisticated as those sixteenth century Europe. If Plato was inspired by the Peloponnesian War, Thomas More was motivated by the crisis in England in 1485 that was changing the entire country, in particular the economic paradigm.

Utopia is an island off the coast of Latin America connected to the land by a waterway, 300 kilometres wide at its widest point, with extremities that narrow and curve round as if to form a circle. This island is a natural harbour and the only visible rock has a tower. Only the inhabitants of Utopia know where it is safe or dangerous to make the crossing. Thus, isolation means voluntary autonomy and independence. Utopia has fifty-four cities and the capital, Amaurot (etymologically meaning "difficult to see"), also called Castle in the Air, lies in the middle of island. Amaurot is surrounded by the River Anider (the river without water) and also has huge defensive walls and river gravel in the city, meaning that it never faces the problem of water scarcity. Every house has a front and a back door and all citizens are proud of their gardens. The main activity is agriculture, taught in schools, together with another occupation. Work is the core of this society and its efficient economy allows for a six-hour working day with no negative impact or disadvantages. Utopia is a republic in which there is no private property and all citizens have common responsibilities and social duties: no one is rich and poverty does not exist. The abolition of private property and money nullifies ambition and greed, so that they never become the basis for crime and abuse. In terms of stratification, the political system is organized around thirty 
families, each of which elects a syphogrant or district controller. Ten syphogrants elect one tranibore, a senior controller, but the whole process is dynamic not static. In the strict sense, Utopia is not an equal society because there is a specific hierarchy: everyone respects and is subordinate to the oldest, women are subordinate to their husbands and children to their parents. Criminals are punished by being made slaves, a category comprising Utopian citizens but also foreigners brought in to work in agriculture. Criminals from Utopia have worse conditions, based on the assumption than if they have enjoyed all the benefits, a good moral education and support and still become bad citizens they deserve the worst punishment. The inhabitants of Utopia enjoy religious freedom but they believe in the soul's immortality, accepting control by a providence inaccessible to our understanding.

In short, the ideal state for both Thomas More and Plato is not a future but a hypothetical ideal, not a normative description but an informing power, and not a goal for action but a possible static model. For both, utopia is a kind of paradigm of justice and common sense which, once established in the mind, clarifies its standards and values. However, if Plato's ideal of city constructs a 'good-place' for Sir Thomas More's term is deliberately ambiguous in its derivation because its root may be taken as ou-topos ('non place') or eu-topos ('good place'). Although Utopia is located on an island, More's state is not eutopia as a good place but outopia as nowhere, separating utopia from the all-too-imperfect real world. This is the ambiguous array also developed by Calvino, a closer concept of ou-topos than eutopos.

\section{archai圈}

n²2, Jan.-Apr. 2018

Ana Martins, 'Invisible cities: utopian spaces or imaginary places?', p. $123-152$ 


\section{archai圈}

no 22, Jan.-Apr. 2018

\section{Ana Martins, 'Invisible} cities: utopian spaces or imaginary places?', p. $123-152$

\section{0}

In theorizing a more perfect world, the writer remains ing from its more positive aspects, reacting against its more negative one, recasting it in the light of social and political theories generated by the imperfect reality from which utopia separates itself. [..] Although utopia's isolation is clearly designed to protect it from contamination by the squalor and disorder of the real world, it can never be so isolated as to be inaccessible to the privileged individual who will eventually return to bear witness to the superiority of the utopian way (FERNS, 1999, p. 2)

Some of the most progressive ideas of the Renaissance had their roots in dreams of magical transformations of the world - dreams which have as their goal, not progress but the restoration of an order, harmony and innocence that had once existed but had long since been lost. This is the same motivation for the emergence of magic realism in Latin America countries. In most utopias the state predominates over the individual: property is usually held in common and the characteristic features of individual life, leisure, privacy and freedom of movement are, as a rule, minimized. The utopia is designed to describe a unified society, not individual forms of existence. However, the principle of paradeigma adopted by Plato reversed the relationship between society and the individual. The ideal or desirable quality in the utopia has to be recognized as manifesting something that the reader can understand as a latent or potential element in his own society and his own thinking. The social aim is an essential and primary human ideal but it is not the only one, nor does it necessarily include others. Human fulfilment has a singular and a dual form, as well as a plural one. The great classical utopias derived their form from city-states 
located in space. Modern utopias derive their form from a uniform pattern of civilization spread over the whole globe and so are thought of as world-states. Whilst the traditional utopia involved a retreat from the notion of utopia as representing a coherent possible alternative to existing society, this role has changed.

\section{IDEAL CITIES: UTOPIAN SPACES OR IMAGINARY PLACES?}

The catalogue offormsisendless: untileveryshapehasfound its city, new cities will continue to be born. When the forms exhaust their variety and come apart, the end of cities begins. (CALVINO, 1974, p. 139)

Having proved intertextualities between Plato and More, a dialogue can also be established, in a diachronic perspective, between More's Utopia and Calvino's approach in Invisible Cities based on the similar number of cities referred to by both authors (fifty-four in Utopia and fifty-five in Calvino's book). In order to provide an overview and understand how images construct these invisibility, Calvino's taxonomy should be examined in greater detail: cities and memory, cities and desire, cities and signs, cities and eyes, cities and names, cities and death, cities and the sky, continuous cities, trading cities, hidden cities.

\begin{tabular}{|l|l|l|l|l|l|}
\hline Order number & 1 & 2 & 3 & 4 & 5 \\
\hline Memory & Diomira & Isidora & Zaira & Zora & Maurilia \\
\hline Desire & Doroteia & Anastásia & Despina & Fedora & Zobaida \\
\hline Signs & Tamara & Zirma & Zoe & Hipácia & Olivia \\
\hline Thin & Isaura & Zenobia & Armila & Sofronia & Octavia \\
\hline Trading & Eufemia & Cloé & Eutrópia & Ersilia & Esmeraldina \\
\hline
\end{tabular}

\section{archai圈}

no 22, Jan.-Apr. 2018

Ana Martins, 'Invisible cities: utopian spaces or imaginary places?', p. $123-152$ 


\section{archai圈}

no 22, Jan.-Apr. 2018

Ana Martins, 'Invisible cities: utopian spaces or imaginary places?', p. $123-152$

\begin{tabular}{|l|l|l|l|l|l|}
\hline Eyes & Valdrada & Zemerude & Bauci & Filias & Moriana \\
\hline Name & Aglaura & Leandra & Pirra & Clarice & Irene \\
\hline Dead & Melania & Adelma & Eusapia & Árgia & Laudomia \\
\hline Sky & Eudoxia & Barsabeia & Tecla & Perinthia & Andria \\
\hline Continuous & Leonia & Trude & Procopia & Cecilia & Pentesileia \\
\hline Hidden & Olinda & Raissa & Marozia & Teodora & Berenice \\
\hline
\end{tabular}

Some of them have an indivisible existence whilst others contain contradictions, some are more ethereal and others much more tangible, but all of them are real in the imagination and only inhabit an abstract space. Is it enough to define some of them as "non-places"/outopia? Their geometries are different and whilst some represent what is necessary but does not exist yet, others represent what is potentially imaginable but not achievable: could this be a coherent definition of utopia as a "good place"/ eutopia? The line between reality and imagination is the same subtle line between the visible and invisible, life and death, truth and verisimilitude. Despite the absence of geographic considerations, Zenobia is a representation of this subtle line and also an example of a thin city proving the impossibility of distinguishing between happy and unhappy cities. It makes no sense to divide cities into these two types, but rather into two different categories: those that over time and through change continue to give form to desires, and those in which desires either erase the city or are erased by it. Intrinsically linked, there are cities like Fedora which represent desires: the impossibility of having what we want together in time and space, as an inescapable karma.

Signs should be a valuable instrument for understanding reality but Zoe demonstrates that ambiguity is constant because the traveller roams everywhere and has only doubts. It is not possible to define the features 
of the city because it is indivisible. What line separates the inside from the outside, the rumble of wheels from the howl of wolves? And what line defines the sky and the city? Perinthia's astronomers are faced with a difficult choice. If they admit that all their calculations were wrong and their figures are unable to describe the heavens, they also must acknowledge that the order of the gods is reflected exactly in the city of monsters. However, hidden cities reflect an important ideal: the purpose is not to define boundaries but to learn and accept the cities as a whole, with cohesion and coherence, despite these contradictions and dialectics. Raissa shows that every unhappy city contains a happy city unaware of its own existence and Marozia, consisting of two cities, the rat's and the swallow's, changes over time, although their relationship does not change; the second is always about to free itself from the first.

All these cities construct a map and a network as a mirror of social relations that are also hidden by trading. For this reason, Chloe's inhabitants can be close and distant at the same time: when a group of people happen to find themselves together, taking shelter from the rain under an arcade, crowding beneath an awning of the bazaar, or stopping to listen to the band in the square, meetings, seductions, couplings and orgies take place without a word exchanged, without a finger touching anything, almost without an eye raised. A voluptuous vibration constantly stirs Chloe, the chestiest of cities.

Trading relations also mean that even the most fixed and calm lives in Esmeraldina can be lived without any repetition. We always live in a dialectical system which contains a poison and its antidote. Berenice has one intrinsic quality: an unjust city is

\section{archai圈}

no 22, Jan.-Apr. 2018

Ana Martins, 'Invisible cities: utopian spaces or imaginary places?', p. $123-152$ 


\section{archai圈}

no 22, Jan.-Apr. 2018

\section{Ana Martins, 'Invisible} cities: utopian spaces or imaginary places?', p. $123-152$

\section{4}

germinating secretly inside the secret just city. For this reason, Berenice is a temporal and continuous succession of different cities, alternately just and unjust, with all the future Berenices are already present in this instant, each inside the other, confined, compacted and inextricable.

Utopia is a combinatorial game, a play on the possibilities calling for a number of pieces that are subject to certain rules which, if the game is to be played well and in an orderly fashion, must be predetermined in time and space. The idea of a chessboard is present in several parts of Invisible Cities and seems essential to deciphering the hidden structure of this book. A chessboard has sixty-four squares and Invisible Cities has seventy three parts, if we add the fifty-five cities to the eighteen dialogues between Polo and Kublai Khan present in all nine chapters. Furthermore, as in a chess board, the pieces are alternately black and white, expressed in Calvino's language by combining a discourse on positive factors with its opposite, a difference that may emerge through the contrast between the discourse in different cities or in the duplicity and ambiguity presented in each one ${ }^{2}$. Moreover, Kublai Khan plays chess and on the basis of Marco Polo's description of each city, the Great Khan's mind sets out on its own, dismantling the city piece by piece to reconstruct it in other ways, substituting certain elements, shifting them and inverting them.

«Kublai Kublai was a keen chess player; following Marco's movements, he observed that certain pieces implied or excluded the vicinity of other pieces and were shifted along certain lines. Ignoring the objects' variety of form, he could grasp the system of arranging one with respect to the others on the majolica floor. He thought: "If each city is like a 
game of chess, the day when I have learned the rules, I shall finally possess my empire, even if I shall never succeed in knowing all the cities it contains [...] Now Kublai Khan no longer had to send Marco Polo on distant expeditions: he kept him playing endless games of chess. Knowledge of the empire was hidden in the pattern drawn by the angular shifts of the knight, by the diagonal passages opened by the bishop's incursions, by the lumbering, cautious tread of the king and the humble pawn, by the inexorable ups and downs of every game» (CALVINO, 1974, p. 121).

Marco Polo clarifies the rules of this game: from the number of imaginable cities we must exclude those whose elements are assembled without any connecting thread or inner rule, a perspective that maintains the cohesion and coherence of the narration. Cities are like dreams: everything imaginable can be dreamed, but even the most unexpected dream is a desire or its reverse, a fear. Cities and dreams are made of desires and fears, even if the thread of their discourse is secret, their rules are absurd, their perspectives deceitful and everything conceals something else. In this way, the traveller presents a catalogue of imaginary spaces but not necessarily utopian places: on the contrary, if the cities reflect fears they can also represent dystopian images ${ }^{3}$ : «Perhaps Adelma is the city where you arrive dying and where each finds again the people he has known. This means I, too, am dead." And I also thought: "This means the beyond is not happy" (CALVINO, 1974, p. 95).

\subsection{REPRESENTATION OF DEATH AS AN IDEAL OF LIFE?}

Through five distinct images of cities related to death, Calvino aims to represent the ideal of life under this inextricable stoic vision defending a inseparable

\section{archai圈}

no 22, Jan.-Apr. 2018

Ana Martins, 'Invisible cities: utopian spaces or imaginary places?', p. $123-152$ 


\section{archai圈}

no 22, Jan.-Apr. 2018

Ana Martins, 'Invisible cities: utopian spaces or imaginary places?', p. $123-152$ dimension. In order to achieve this purpose, he manages different aspects concerning this subject: the claim for self-knowledge, the perpetuation of life and the perception of an unknown world as a continuous reality, the relationship with time and with an unpredictable end, the problem of dealing with death, the problematic establishment of authorities in matters of faith, literature's inability to convincingly discuss the afterlife.

Melania is the first of these cities and the name means "black" because in Greek mythology Melania was a Corycian nymph who ruled over matters of the underworld and the unseen. The main paradox lies in the fact that Melania's identity relies on the perpetual dialogue between the inhabitants, whereas their lifespan is limited. Melania needs to find a solution to the mortality of its inhabitants in order to survive, and the problem is resolved by renewing the population. Melania is similar to a living organism that needs to adapt and develop a specific mechanism in order to bypass the problems that prevent it from functioning normally. Sum up, the solution does not rely on making the inhabitants immortal, but rather on finding a way to keep the dialogue going despite their mortality. The dynamic of this city develops through the replacement of those who die with others, the redistribution and multiplication of roles in order to match the number of people in the city, or even the division of one into several different roles. Their lives are not too short to develop conflicts but without time enough to heal and to solve them and, consequently, to change the status quo.

Adelma means 'old', metaphorically interconnected with the moment when traveller arrives at dusk. 
It is no coincidence that the traveller should be reminded of all the old people he had once known. It is the city where the traveller once again sees those he has known and who have died. The dilemma he confronts is whether to look at the faces he has known or not. When the realm of the dead apparently meets that of the living and all frontiers are shattered, doubt and anxiety become inevitable. He finds himself constantly facing death and is terrified by it, and at the same time his memories become quite blurred and he finds it difficult to interpret similarities and tell people apart. One important topic, which belongs to the long literary and mythical tradition of the underworld, is the idea of looking death in the eye.

No city is more inclined than Eusapia to enjoy life and flee care, even being a city of the dead. Eusapia has its own particular way of dealing with the issue of the afterlife. In the beginning we are told that in order to make the passage to the afterlife somewhat less abrupt, the inhabitants of Eusapia have built an identical city to theirs below ground where the dead continue their activities and sometimes find themselves in different, more pleasant circumstances than when they were still alive. Eusapia (Eusebia) means "pious" and in the city there is a specific group of people responsible for accompanying the dead to their new realm. They are first described as a brotherhood, and then referred to as a congregation. Although the words "religion" and "church" are not to be found in the text, the description of the city of Eusapia clearly discusses the role of an established religious organization in matters of faith, especially those related to the belief in an afterlife. If the inhabitants of Eusapia want to know about the city that they will go to in the afterlife, they have

\section{archai圈}

no 22, Jan.-Apr. 2018

Ana Martins, 'Invisible cities: utopian spaces or imaginary places?', p. 123-152 


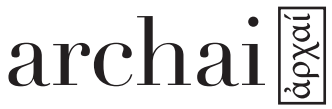

no 22, Jan.-Apr. 2018

Ana Martins, 'Invisible cities: utopian spaces or imaginary places?', p. 123-152 to take their word for granted. Another level of interpretation consists of understanding how in general our reality and the choices that we make about our terrestrial life are very often conditioned by the image we create of an afterlife. Sometimes the hooded mediators who lead the dead to the other Eusapia in the underground acknowledge the innovations created by dead people, since in the afterlife they are more lucid and thoughtful. For this reason, the living people in Eusapia try to imitate the "avatar". In short, it is impossible to distinguish who is alive and who is dead in the twin cities because the dividing line is very thin.

Argia is described as a city constructed to be covered by tons of soil. Its darkness and density make it motionless and impenetrable to all the senses. The description of Argia is also the shortest of the five and this is significant since there is not much that can be told about this city which no one knows anything about even when, paradoxically, the name Argia means light.

Laudomia is a city with a triple structure and dynamic: the first is for the living inhabitants, the second is reserved for the dead and the third is for those still unborn. If the three dimensions we have for time past, present, future - do not coexist, they are at least perpetually present in our concerns. The importance that the people of Laudomia attribute both to the past and the future is reflected in the size of these sibling cities. The issues raised by Laudomia are the main philosophical questions that humankind has always pondered (Petsota, 2012).

In conclusion, the representation of death (outopos) is an attempt to define the ideal of life (eutopos). 
For this reason, utopianism is a tension, the aspiration to move beyond the fixity of the present, offering a vision which is a radical alternative to the reality in which the writer lives and operates. The essence of utopia lies precisely in its inherent ambiguity, in its interplay between a design which is not-yet-real and the reality which the design contests. This ambivalence constitutes both the strength and weakness of the genre: its strength as utopia lies in its tension with elsewhere, the capacity to imagine the other; its weakness is the fact that its paradigm is essentially only an abstraction of the real.

There is one final question: does utopia therefore fail where reality begins? If men and women began to live their ephemeral dreams, every phantom would become a person with whom to begin a story of pursuits, misunderstandings, clashes, oppressions and the carousel of fantasies would stop. Northrop Frye confirms: "the world you want to live in is not the world you see but the world you build out of what you see» (1974, p.19) So, where is utopia? Perhaps it is just right here and right now.

\section{Notas}

1 It is nowadays thought that Erasmus was encouraged by Thomas More to write Eucomium Moriae (Moria, from Greek means madness).

2 «Nel percorso di conoscenza di Marco e Kublai coabitano due indirizzi di pensiero contrastanti: da un lato vi è la tendenza a vedere nell'oggetto il simbolo di una totalità straordinaria e trascendente, a cui tutto viene a tempo debito ricondotto, dall'altro la tendenza a percepire nell'oggetto un frammento di un'unità non ripristinabile. Il frammento

\section{archai蒡}

no 22, Jan.-Apr. 2018

Ana Martins, 'Invisible cities: utopian spaces or imaginary places?', p. $123-152$ 


\section{archai圈}

no 22, Jan.-Apr. 2018

Ana Martins, 'Invisible cities: utopian spaces or imaginary places?', p. $123-152$ introdurrebbe insomma una dissonanza, una nota disarmonica nell'universo, puntando l'attenzione sulle sue discordanze, segnalandone il disordine, metendone in dubbio il contenuto epistemico. La visione opposta trasforma invece il frammento in uno strumento di investigazione ed interpretazione dell'infinito. Così, mentre Marco traduce il messaggio esperienziale nella plasticità di immagini sfuggenti e metamorfiche, l'imperatore oscilla tra la speranza di scorprire in questa struttura precise rette ordinatrici e la disperazione di non rinvenire ni essa che disarmonia e caos», in Simonetta Chessa Wright (1998, p. 71-72).

3 «While the traditional utopia seeks to forestall critical judgement of the alternative society, utopia constituting the standard by which our own world is judged and found wanting, dystopian fiction positively demands that readers judge the projected society by the standards of their own», Chris Ferns (1999, p. 109).

\section{BIBLIOGRAPHY}

BLOCH, Ernst (1988). The utopian function of art and literature: selected essays, ZIPES, Jack; MECKLENBURG, Frank (transl.). Cambridge/ London, MIT Press.

CALVINO, Italo (1974). Invisible Cities, WEAVER, William (transl.). San Diego, New York, London, Harcourt Brace \& Company.

CLAEYS, Gregory (2011). Searching for Utopia: the history of an Idea. London: Thames \& Hudson.

DELGADO, José Manuel Camacho (2006). Comentarios Filológicos sobre el realismo mágico. Madrid: Arco/Libros, S.L.

FERGUSON, F. (1975). Utopias of the classical world. London, Thames and Hudson. 
FERNS, Chris (1999). Narrating utopia: ideology, gender, form in utopian literature. Liverpool, University Press. https://doi.org/10.5949/liverpool/9780853235941.001.0001

FRASSON-MARIN, Aurore (1986). Italo Calvino et l'imaginaire. Génève-Paris, Slatkine.

FRYE, Northrop (1985). Varieties of Literary Utopias. Daedalus, 94, 2, p. 323-347.

FRYE, Northrop (1990). Myth and metaphor: selected essays. Ed. by Robert Denham. Charlottesville: University Press of Virginia.

GRENDLER, P.F. (1965). Utopia in Renaissance Italy: Doni's New World. Journal of the History of Ideas 26, 4, p. 479-483. https://doi.org/10.2307/2708495

JACOB, Johanna (1998). Calvino's reality: designer's utopia? Utopian Studies 1, p. 103-119.

JONES, Clint; CAMERON, Ellis (2015). The individual and Utopia: a multidisciplinary study of $\mathrm{Hu}$ manity and Perfection. London/New York, Routledge.

LACROIX, Jean-Yves, (2007). L'Utopia de Thomas More et la tradition platonicienne. Paris, Vrin.

MARIN, Louis (1973). Utopiques: jeux despaces. Paris, Les éditions de Minuit.

MUCCHIELLI, Roger (1961). Le Mythe de la cité idéale. Paris, Presses universitaires de France.

PETSOTA, Myrto (1977). Italo Calvino: Mythical writing in an enlightened world, desire, utopia and earthly

\section{archai綮}

no 22, Jan.-Apr. 2018

Ana Martins, 'Invisible cities: utopian spaces or imaginary places?', p. $123-152$ 


\section{$\operatorname{archai}$ 圈}

no 22, Jan.-Apr. 2018
Ana Martins, 'Invisible cities: utopian spaces or imaginary places?', p. $123-152$ transcendence in the cosmicomic stories. $\mathrm{PhD}$ thesis - The University of Edinburgh Oilthigh Dhun Eideann, 2012.

SEVILLA FERNÁNDEZ, José Maria; BARRIOS CASARES, Manuel (eds.) (2000). Metáfora y discurso filosófico. Madrid, Editorial Tecnos, Madrid.

TROUSSON, Raymond (1975). Voyages aux pays de nulle part : histoire littéraire de la pensée utopique. Bruxelles, Éditions Universitaires de Bruxelles.

WEBB, Jenny (2011). Fantastic, Desire. Poe, Calvino and the Dying Woman. The Comparatist 35, p. 211-220. https://doi.org/10.1353/com.2011.0029

WRIGHT, Simonetta Chessa (1998). La poetica neobarocca in Calvino. Ravenna, Longo Editore.

TODOROV, Tzvetan (1970). Introduction à la littérature fantastique. Paris, Éditions du Seuil.

Submetido em Julho e aprovado para publicação em Agosto, 2016 